Quim. Nova, Vol. 35, No. 8, 1606-1611, 2012

\title{
HIGHLY IMPROVED CHROMIUM (III) UPTAKE CAPACITY IN MODIFIED SUGARCANE BAGASSE USING DIFFERENT CHEMICAL TREATMENTS
}

\author{
Vanessa Cristina Gonçalves Dos Santos, Antonio de Pádua Andrade Salvado e Douglas Cardoso Dragunski* \\ Universidade Paranaense, Praça Mascarenhas de Moraes, 87502-210 Umuarama - PR, Brasil \\ Débora Nobile Clausen Peraro e César Ricardo Teixeira Tarley \\ Departamento de Química, Universidade Estadual de Londrina, Rod. Celso Garcia PR 445 km 380, 86051-990 Londrina - PR, Brasil \\ Josiane Caetano \\ Departamento de Engenharias e Ciências Exatas, Universidade Estadual do Oeste do Paraná, 85903-000 Toledo - PR, Brasil
}

Recebido em 29/8/11; aceito em 16/3/12; publicado na web em 3/7/12

\begin{abstract}
The present paper focuses on improving chromium (III) uptake capacity of sugarcane bagasse through its chemical modification with citric acid and/or sodium hydroxide. The chemical modifications were confirmed by infrared spectroscopy, with an evident peak observed at $1730 \mathrm{~cm}^{-1}$, attributed to carbonyl groups. Equilibrium was reached after $24 \mathrm{~h}$, and the kinetics followed the pseudosecond-order model. The highest chromium (III) maximum adsorption capacity (MAC) value was found when using sugarcane bagasse modified with sodium hydroxide and citric acid (58.00 $\left.\mathrm{mg} \mathrm{g}^{-1}\right)$ giving a MAC value about three times greater $\left(20.34 \mathrm{mg} \mathrm{g}^{-1}\right)$ than for raw sugarcane bagasse.
\end{abstract}

Keywords: biosorption; chromium; sugarcane bagasse.

\section{INTRODUCTION}

As a result of growing industrial activity, many chemicals such as heavy metals, organic compounds and synthetic materials pose serious environmental contamination problems, resulting in ecosystem deterioration. ${ }^{1,2}$ Chromium is considered a heavy metal and a cause of wastewater treatment problems. The CONAMA (National Council for the Environment, Brazil) Resolution 357 established $0.05 \mathrm{mg} \mathrm{L}^{-1}$ as the allowable limit of chromium in water, whereas the EPA (US Environmental Protection Agency) set this limit at $0.1 \mathrm{mg} \mathrm{L}^{-1} \cdot 3-5$

Under some circumstances, chromium is an important element for the environment and even for human health. It occurs primarily in two forms: trivalent chromium (III) and hexavalent chromium (VI). The biochemical functions and effects of chromium are dependent on its oxidation state: chromium (VI) is carcinogenic, whereas chromium (III) is considered essential for humans. The largest sources of chromium (VI) are anthropogenic, derived mainly from textile industries, oil refineries and galvanizing plants, where it is dispersed into the environment through air or water emissions. ${ }^{6,7}$

Chromium (VI) originates from the oxidation of chromium (III). The constant accumulation of trivalent species, associated with certain soil conditions, can be intensified in the presence of oxidized manganese, low carbon levels and good aeration, thus promoting the oxidation of chromium (III) to its hexavalent form, which is potentially hazardous to human health and environmental balance. Chromium (III) is found naturally in small quantities in the body, and performs important functions, particularly concerning glucose metabolism. ${ }^{8,9}$ Nevertheless, prolonged exposure to trivalent species may also cause skin allergies and cancer in human beings. ${ }^{10,11}$

Several conventional methods of removing heavy metals from industrial effluents such as reduction, chemical precipitation, filtration and ion exchange, are possible approachs for chromium concentration level reduction. ${ }^{3,9}$ However, these conventional techniques are considered expensive, in addition to requiring a long detention time,

*e-mail: dcdragunski@unipar.br which hinders their implementation, especially when the metals are dissolved in large volumes of water. The generation of stored and stocked solid waste, causing an additional serious problem, appears to be another drawback of using these techniques. ${ }^{12-14}$

Studies on the development of effluent treatments containing heavy metals have indicated that adsorption is a highly effective and inexpensive alternative process among the various treatments available for removing heavy metal ions. ${ }^{9,13}$ The adsorption phenomena have been observed when the accumulation of a particular element or substance takes place at the interface between two phases, i.e., between a solid surface and an adjacent solution. ${ }^{13}$ However, the adsorption also generates a solid residue that could be incinerated and then embedded in concrete blocks.

In recent years, many studies have been carried out to evaluate the effectiveness of methods for removing large amounts of chromium from industrial effluents using economically viable adsorbents based on agro-industrial residues, such as carrot residues, raw rice bran, vineyard pruning waste, bacteria from tannery effluent contaminated soil and castor seed hull. ${ }^{14-19}$ Adsorption of heavy metals by agro-industrial residues is commonly called biosorption; it describes a property of the non-living biomass to retain metal ions as a result of electrostatic interactions and complex formations between these ions and functional groups present in the biomass. ${ }^{20}$ The mechanisms responsible for the interaction of metal ions with the structure of these materials are determined by the identification of functional groups, such as carboxylate, phosphate and amino groups, which are typically important for the biosorption process. ${ }^{19,21-23}$ Biosorption capacity could be significantly increased by performing a chemical modification of the biomass surface. For instance, chemically modified sugarcane bagasse, an agro-industrial residue widely available in Brazil, has been recently employed for the adsorption of copper, cadmium, lead, nickel, zinc, magnesium and calcium from aqueous solutions. In these studies, ethylenediamine-tetraacetic dianhydride (EDTAD), sulfuric acid and succinic anhydride were utilized as modifying agents. ${ }^{24-26}$

The present work demonstrates, for the first time, the reliable use of sugarcane bagasse as an alternative material for chromium 
(III) removal from aqueous solutions by using chemical treatments with citric acid and/or sodium hydroxide. Despite published studies investigating sugarcane bagasse chemical modification, the advantages of the proposed treatment with citric acid and/or sodium hydroxide include low-cost, quick and easy operation conditions and, most importantly, highly improved metal ion uptake capacity in comparison with raw sugarcane bagasse. The applicability of Langmuir and Freundlich isotherms and thermodynamic parameters for chromium (III) adsorption in chemically modified sugarcane bagasse was also evaluated.

\section{EXPERIMENTAL}

\section{Reagents}

Analytical grade chemical reagents were used in this study. A $1000 \mathrm{mg} \mathrm{L}^{-1}$ chromium stock solution was prepared from chromium nitrate $\left(\mathrm{Cr}\left(\mathrm{NO}_{3}\right)_{3}\right.$ Vetec, 99\%), and required dilutions were carried out with deionized water. Solutions of $0.1 \mathrm{~mol} \mathrm{~L}^{-1} \mathrm{NaOH}$ (F. Maia, 97\%), $0.1 \mathrm{~mol} \mathrm{~L}^{-1} \mathrm{HCl}$ (F. Maia, 37\%) and $1.2 \mathrm{~mol} \mathrm{~L}^{-1} \mathrm{HNO}_{3}$ were used for $\mathrm{pH}$ adjustment.

\section{Equipment}

A Bomem FT-IR MB-102 infrared spectrometer was used to elucidate the functional groups present in the adsorbents. Sugarcane bagasse samples were proportionally macerated with $\mathrm{KBr}$ crystals (1 mg sample/100 mg KBr), placed into a pastillator and analyzed in the 4000-400 $\mathrm{cm}^{-1}$ spectral range. A GBC 932 Plus flame atomic absorption spectrometer (FAAS), equipped with a deuterium lamp for background correction and a hollow cathode lamp as a radiation source for chromium, was used to quantify the metal.

\section{Adsorbent preparation - sugarcane bagasse modifications}

Sugarcane bagasse was obtained at the Santa Terezinha Mills (Ivaté, Paraná State, Brazil). The material was ground and sieved through a 100-mesh sieve (Bertel, São Paulo, Brazil) prior to use in order to obtain a more homogenous particle size. Furthermore, three chemical modifications were performed.

\section{Modification using $\mathrm{NaOH}(B-S)$}

To carry out the sugarcane bagasse modification with $\mathrm{NaOH}$ (B-S), $20 \mathrm{~mL}$ of $0.1 \mathrm{~mol} \mathrm{~L}^{-1} \mathrm{NaOH}$ solution was added per gram of material, the mixture agitated for $2 \mathrm{~h}$, and the supernatant discharged. Subsequently, the material was repeatedly washed with deionized water and dried at $55{ }^{\circ} \mathrm{C}$ for $24 \mathrm{~h}$. This procedure was performed to withdraw any impurities that could affect the effluent quality. ${ }^{23,25}$

\section{Modification using citric acid (B-CA)}

To carry out the second sugarcane bagasse treatment using citric acid (B-CA), a $1.2 \mathrm{~mol} \mathrm{~L}^{-1}$ citric acid solution was added to the bagasse at a ratio of $8.3 \mathrm{~mL}$ solution $/ 1 \mathrm{~g}$ bagasse. Subsequently, the mixture was agitated for $30 \mathrm{~min}$, and the supernatant discharged. The bagasse was dried at $55^{\circ} \mathrm{C}$ for $24 \mathrm{~h}$ after which the temperature was increased to $120^{\circ} \mathrm{C}$, and the sample kept for $90 \mathrm{~min}$. Next, the bagasse was repeatedly washed with deionized water and dried at $55^{\circ} \mathrm{C}$ for 24 h..$^{23,25}$

\section{Modification using $\mathrm{NaOH}$ and citric acid (B-CAS)}

For the third treatment, the sugarcane bagasse was chemically modified with both $\mathrm{NaOH}$ and citric acid (B-CAS). To perform this procedure, $20 \mathrm{~mL}$ of $0.1 \mathrm{~mol} \mathrm{~L}^{-1} \mathrm{NaOH}$ solution was added per gram of material, the mixture was agitated for $2 \mathrm{~h}$, and the supernatant discharged. Next, the material was repeatedly washed with deionized water and dried at $55^{\circ} \mathrm{C}$ for $24 \mathrm{~h}$. Subsequently, $8.3 \mathrm{~mL}$ of 1.2 mol L ${ }^{-1}$ citric acid solution was added per gram of bagasse and the mixture agitated for $30 \mathrm{~min}$. Then, the supernatant was discharged, and the bagasse was dried at $55{ }^{\circ} \mathrm{C}$ for $24 \mathrm{~h}$. The temperature was then raised to $120{ }^{\circ} \mathrm{C}$, and the sample kept for $90 \mathrm{~min}$. Finally, the bagasse was repeatedly washed with deionized water $\left(60-80{ }^{\circ} \mathrm{C}\right)$ and dried at $55^{\circ} \mathrm{C}$ for $24 \mathrm{~h}^{23,25}$

\section{Metal adsorption experiment}

\section{Adsorption as a function of time}

The adsorption of chromium ions on the modified bagasse (B-S, $\mathrm{B}-\mathrm{CA}$ and $\mathrm{B}-\mathrm{CAS})$ and raw sugarcane bagasse (B-N) was carried out by agitating $50 \mathrm{~mL}$ of $1000 \mathrm{mg} \mathrm{L}^{-1} \mathrm{Cr}$ (III) solutions at $\mathrm{pH} 5.0$ with $0.5 \mathrm{~g}$ of bagasse on an orbital shaker. Ten aliquots of $500 \mu \mathrm{L}$ were collected from the supernatant at time intervals ranging from 15 to $1440 \mathrm{~min}$, and deionized water was added until the volume reached $50 \mathrm{~mL}$. Some studies have reported that the maximum adsorption capacity of some metals in biomass could be achieved at a $\mathrm{pH}$ of around 5.0. Therefore, this $\mathrm{pH}$ value was chosen to perform the experiments. ${ }^{25,29,30}$ The chromium concentration was determined by FAAS, all the measurements were made in triplicate. Necessary correction for the amount of chromium ions in the initial solution was carried out for each aliquot. The amount of metal adsorbed per gram of bagasse $\left(\mathrm{q}_{\mathrm{t}}\right)$ as a function of time was calculated as follows:

$$
q_{t}=\frac{\left(C_{0}-C_{e q}\right) * V}{M}
$$

where, $\mathrm{C}_{0}$ and $\mathrm{C}_{\mathrm{eq}}$ are the metal initial and equilibrium concentrations, respectively, in the solution $\left(\mathrm{mg} \mathrm{L}^{-1}\right), \mathrm{V}$ is the solution volume $(\mathrm{mL})$, and $\mathrm{M}$ is the bagasse mass $(\mathrm{g})$.

\section{Adsorption isotherms}

Chromium (III) solutions were prepared at different concentrations ranging from 100 to $1000 \mathrm{mg} \mathrm{L}^{-1}$. Subsequently, $50 \mathrm{~mL}$ of these solutions was individually used at $\mathrm{pH} 5.0$ and agitated with $0.5 \mathrm{~g}$ of bagasse on an orbital shaker for $24 \mathrm{~h}$. The study was conducted at room temperature $\left(25^{\circ} \mathrm{C}\right)$. The mixtures were then filtered, and the solutions analyzed by FAAS. All measurements were made in triplicate. The amount of metal adsorbed per gram of bagasse was calculated according to Equation 1, and the plot of $\mathrm{q}_{\mathrm{eq}}$ as a function of $\mathrm{C}_{\mathrm{eq}}$ was built.

\section{Adsorption as a function of temperature}

For the analysis of adsorption as a function of temperature, $0.5 \mathrm{~g}$ of the sugarcane bagasse residue samples, natural and modified, were put in contact with $50 \mathrm{~mL}$ of $100 \mathrm{mg} \mathrm{L}^{-1}$ chromium solution at $\mathrm{pH}$ 5.0 and agitated for $24 \mathrm{~h}$ at various temperatures: 10, 20, 30, 40 and $60{ }^{\circ} \mathrm{C}$. The $\mathrm{q}_{\mathrm{eq}}$ value was next calculated, and these data were used to estimate the following thermodynamic parameters: enthalpy $(\Delta \mathrm{H})$, Gibbs free energy $(\Delta \mathrm{G})$ and entropy $(\Delta \mathrm{S})$.

\section{Desorption experiment}

The assay to evaluate the chromium desorption from materials was carried out by loading the bagasse with a known chromium amount (890 $\mathrm{mg} \mathrm{L}^{-1}$ ), followed by washing with $150 \mathrm{~mL}$ of Milli-Q water and drying in an oven at $50{ }^{\circ} \mathrm{C}$ for $24 \mathrm{~h}$. After this period, the bagasse was soaked in $50 \mathrm{~mL}$ of $0.1 \mathrm{~mol} \mathrm{~L}^{-1} \mathrm{HCl}$ solution for chromium recovery. 


\section{RESULTS AND DISCUSSION}

\section{Adsorbent characterization}

Figure 1 shows the infrared spectra of the modified and raw sugarcane bagasse. The broad peak between 3412 and $3420 \mathrm{~cm}^{-1}$ is indicative of the existence of bonded hydroxyl groups in macromolecular associations (cellulose). The peak observed at $2916 \mathrm{~cm}^{-1}$ can be assigned to the $\mathrm{C}-\mathrm{H}$ group. The bands at around 1650 and 1750 $\mathrm{cm}^{-1}$ represent free and esterified carboxyl groups. Moreover, the peak that appears at around $1639 \mathrm{~cm}^{-1}$ is due to its strengthening and the CO stretching vibration of carboxylic acid.

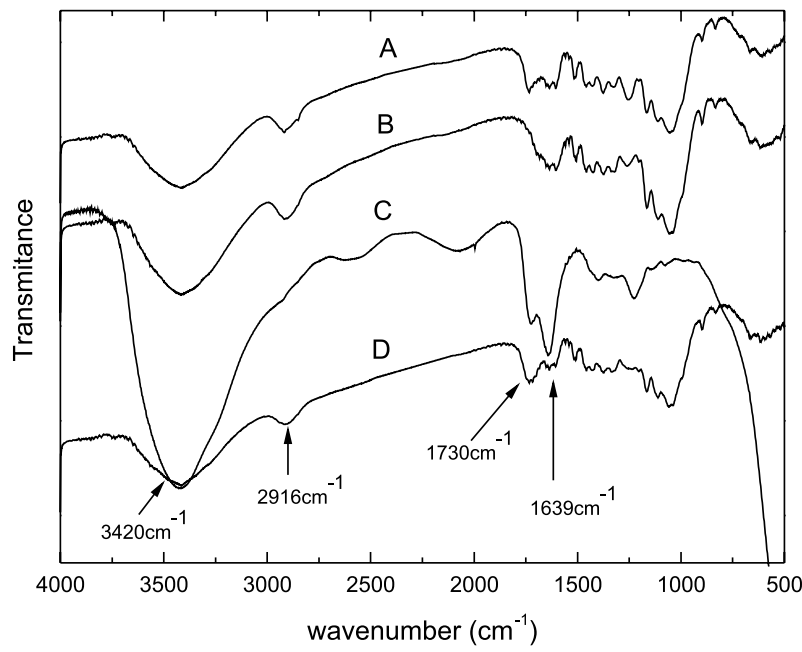

Figure 1. FTIR spectra of $B-N(A) ; B-S(B) ; B-C A(C) ; B-C A S(D)$

After the bagasse modification with citric acid (Figure 1, C and D), the peak at $1730 \mathrm{~cm}^{-1}$, evidencing the presence of carboxyl groups, was observed. Such results corroborate the study done by Rodrigues et al. ${ }^{23-25}$ in which the occurrence of carboxyl groups in Paraju sawdust after treating with $\mathrm{NaOH}$ and citric acid was verified. Considering that carboxyl groups present in raw adsorbents are usually weak acids and generate negative sites in a moderately acid medium, the interaction between cations in a solution becomes easier. According to the authors, ${ }^{13,25,31,32}$ the adequate $\mathrm{pH}$ for these sites to become more reactive is usually around $\mathrm{pH}$ 5.0. In addition, due to the fact that chromium (III) ions precipitate in the solution as chromium hydroxides at $\mathrm{pH}>6.0$ (as shown by the speciation diagram in Figure 2), $\mathrm{pH} 5.0$ was chosen for the present study experiments, and was adjusted with $0.1 \mathrm{~mol} \mathrm{~L}^{-1}$ hydrochloric acid or sodium hydroxide.

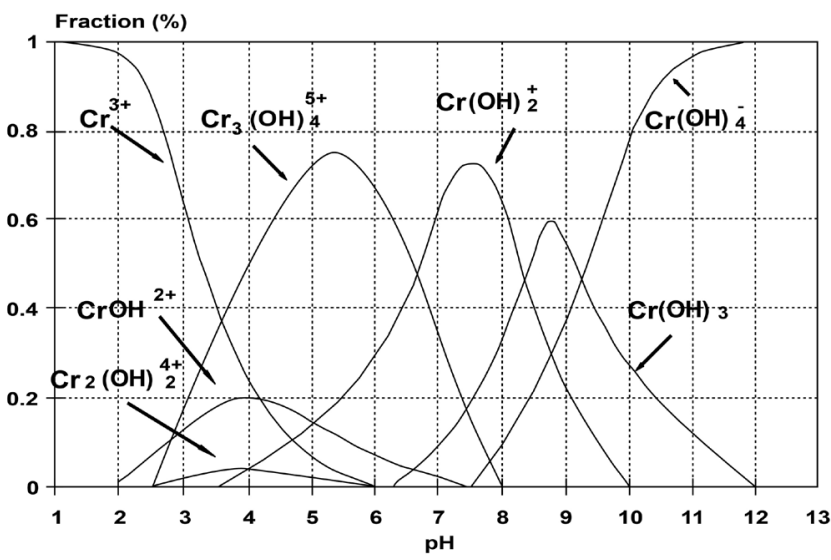

Figure 2. Chromium (III) speciation diagram

\section{Effect of time on adsorption}

Figure 3 depicts chromium (III) adsorption on the B-S, B-C, B-CAS and B-N materials as a function of agitation time. The highest adsorption value was obtained for B-CAS. Therefore, it was initially observed that the chemical modifications improved the adsorbing properties of the sugarcane bagasse samples. Regarding agitation time, it was noted that, for all the experiments, most of the chromium was adsorbed within the first $500 \mathrm{~min}$; however, a slight increase in adsorption was verified after $500 \mathrm{~min}$. The system tended to reach equilibrium after approximately $1440 \mathrm{~min}(24 \mathrm{~h})$. In another study, ${ }^{33}$ succinylated mercerizced cellulose was utilized to investigate chromium (VI) adsorption, and the equilibrium for chromium (VI) adsorption was reached in approximately $300 \mathrm{~min}$. The bagasse chemical treatment (acid/base) led to strong fiber delignification, increasing the space within the fibers for metal adsorption.

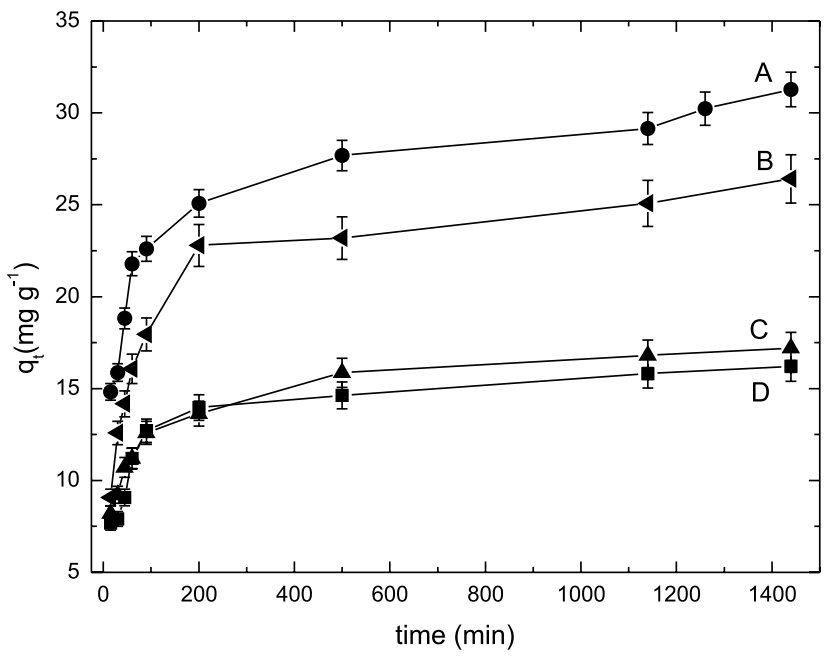

Figure 3. Chromium (III) adsorption on B-CAS (A- $\mathbf{-}), B-S(B-\mathbf{\Delta}), B-C A(C-$ and $B-N(D-4)$ as a function of time. Temperature: $25^{\circ} \mathrm{C}, \mathrm{pH}: 5.0$

The data presented in Figure 3 provide a description of the kinetics for each adsorbent by using pseudo-first-order and pseudo-second-order models. The pseudo-first order kinetics follows the Lagergren model expressed by Equation 2. 14,31,33-35

$$
\log \left(q_{e q}-q_{t}\right)=\log q_{e q}-\frac{K_{1} t}{2.303}
$$

where $\mathrm{q}_{\mathrm{t}}$ is the amount of adsorbed metallic ions $\left(\mathrm{mg} \mathrm{g}^{-1}\right)$ at time $\mathrm{t}$ ( $\mathrm{min}$ ), and $\mathrm{K}_{1}$ is the pseudo-first-order constant $\left(\mathrm{min}^{-1}\right)$; $\mathrm{q}_{\mathrm{eq}}$ and $\mathrm{K}_{1}$ can be calculated using the linear and angular coefficients, respectively, of the $\log \left(\mathrm{q}_{\mathrm{eq}}-\mathrm{q}_{\mathrm{t}}\right)$ plot as a function of time. Comparing the $\mathrm{q}_{\mathrm{eq}}$ experimental values with those obtained from Equation 2, reveals differences between them (Table 1). In addition, the $r^{2}$ values are far from unity, suggesting that the adsorption does not fit the first-order reaction.

Therefore, the pseudo-second-order model (Equation 3) was applied to the metal adsorption kinetics. . $^{14,31,33-35}$

$$
\frac{t}{q_{t}}=\frac{1}{K_{2} q_{e q}{ }^{2}}+\frac{t}{q_{e q}}
$$

where $\mathrm{k}_{2}$ is the pseudo-second-order constant $\left(\mathrm{g} \mathrm{mg}^{-1} \mathrm{~min}^{-1}\right)$ obtained from the angular coefficient of the linear plot $\left(\mathrm{t}_{\mathrm{q}} \mathrm{q}_{\mathrm{t}} v s \mathrm{t}\right)$, and $\mathrm{q}_{\mathrm{eq}}$ can be calculated using the linear coefficient. The $\mathrm{q}_{\mathrm{eq}}, \mathrm{k}_{2}$ and $\mathrm{R}^{2}$ experimental and calculated values are shown in Table 1. 
Table 1. Chromium (III) adsorption pseudo-first-order and pseudo-second-order kinetic model parameters

\begin{tabular}{|c|c|c|c|c|c|c|c|}
\hline \multirow[b]{2}{*}{ Material } & \multirow{2}{*}{$\underset{(\exp .)}{\mathrm{q}_{\mathrm{eq}}}\left(\mathrm{mg} \mathrm{g}^{-1}\right)$} & \multicolumn{3}{|c|}{ Pseudo-first-order kinetics } & \multicolumn{3}{|c|}{ Pseudo-second-order kinetics } \\
\hline & & $\mathrm{K}_{1}$ & $\begin{array}{c}\mathrm{q}_{\mathrm{eq}} \\
\text { (cal.) }\left(\mathrm{mg} \mathrm{g}^{-1}\right)\end{array}$ & $\mathrm{R}^{2}$ & $\mathrm{~K}_{2}$ & $\begin{array}{c}\mathrm{q}_{\mathrm{eq}} \\
(\text { cal. })\left(\mathrm{mg} \mathrm{g}^{-1}\right)\end{array}$ & $\mathrm{R}^{2}$ \\
\hline $\mathrm{B}-\mathrm{N}$ & 16.21 & $2.58 \times 10^{-3}$ & 6.33 & 0.889 & $2.13 \times 10^{-3}$ & 16.10 & 0.999 \\
\hline B-S & 26.41 & $2.09 \times 10^{-3}$ & 11.49 & 0.803 & $1.12 \times 10^{-3}$ & 25.71 & 0.999 \\
\hline $\mathrm{B}-\mathrm{CA}$ & 17.20 & $2.67 \times 10^{-3}$ & 7.10 & 0.954 & $1.87 \times 10^{-3}$ & 17.15 & 0.999 \\
\hline B-CAS & 31.28 & $1.84 \times 10^{-3}$ & 12.20 & 0.908 & $1.10 \times 10^{-3}$ & 30.40 & 0.999 \\
\hline
\end{tabular}

Considering regression coefficient values for the pseudo-first-order and pseudo-second-order kinetic models, it is evident that the latter has a good fits to the experimental data. Moreover, the $\mathrm{q}_{\mathrm{eq}}$ values of this model are superior to those obtained from the pseudo-first-order model and closer to those experimentally obtained, confirming that adsorption is controlled by a strong interaction which follows the pseudo-second-order kinetics.

\section{Adsorption isotherms}

The adsorption isotherms (Figure 4) were constructed by setting the equilibrium time between the adsorbate and adsorbent at 1440 min. A three-fold improvement in the adsorption for B-CAS was confirmed versus the raw bagasse. Similar results were observed in the study of chromium adsorption on Hevea Brasilinesis charcoal sawdust ${ }^{33}$ and similarly by other works. ${ }^{10,11,14,15,17,32}$ High adsorption efficiency provided by chemical modifications can also be assessed for other natural materials. The results obtained by Garcia-Reye and Rangel-Mende $\mathrm{z}^{17}$ with agave bagasse used for chromium adsorption showed lower $\mathrm{q}_{\mathrm{eq}}$ values than those observed for B-CAS. The isotherm constructed for B-S had a different format compared with the other materials. According to Giles and coworkers, ${ }^{36}$ this isotherm type represents a rare case where, at high adsorbate concentrations, adsorbate-adsorbate interactions are favorable and increase rapidly in comparison with adsorbate-adsorbent interactions.

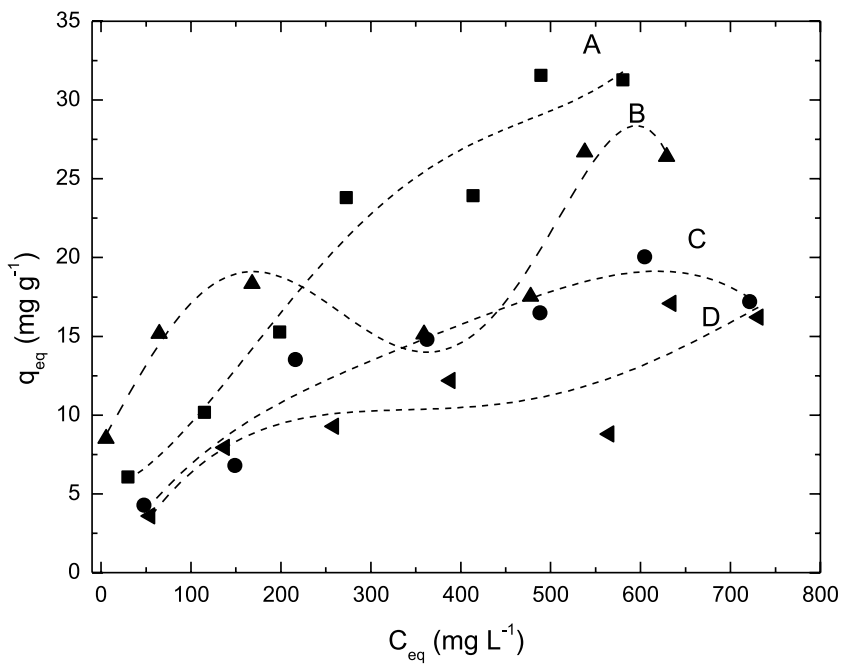

Figure 4. Chromium (III) adsorption isotherms for $B-C A S$ ( $A-\mathbf{-}), B-S(B-\mathbf{\Delta})$, $B$-CA $(C-\bullet)$ and $B-N(D-4)$. Temperature: $25^{\circ} \mathrm{C}, \mathrm{pH}: 5.0$, agitation time: $24 \mathrm{~h}$

In order to verify the adsorption behavior of chromium ions onto the materials, non-linearized isotherms were applied using the MATLAB 7.0.1 - cftool software, as well as Langmuir (Equation 4), Freundlich (Equation 5), Two-site Langmuir (Equation 6) and Radke-Prausnitz (Equations 7) models.

$$
q_{e q}=\frac{q_{m} b C_{e q}}{1+b C_{e q}}
$$

where $\mathrm{b}$ is the adsorption intensity constant, $\mathrm{q}_{\mathrm{m}}$ is the capacity indicating maximum adsorption intensity. ${ }^{37,38}$

$$
q_{e q}=K_{f} C_{e q}^{\frac{1}{n}}
$$

where $K_{f}$ is the adsorbate-adsorbent affinity parameter; $1 / n$ is the adsorbent surface heterogeneity factor. ${ }^{37-39}$

$$
q_{e q}=\frac{b_{A} K_{A} C_{e q}}{1+K_{A} C_{e q}}+\frac{b_{B} K_{B} C_{e q}}{1+K_{B} C_{e q}}
$$

The two-site Langmuir model represents four sorption parameters $\left(\mathrm{b}_{\mathrm{A}}, \mathrm{K}_{\mathrm{A}}, \mathrm{b}_{\mathrm{B}}\right.$ and $\left.\mathrm{K}_{\mathrm{B}}\right){ }^{40}$

$$
q_{e q}=a_{R} b_{R} \frac{C_{e q}^{\propto R}}{a_{R}+b_{R} C_{e q}^{\propto R-1}}
$$

where $a_{R}, b_{R}$ and $\alpha_{R}$ are the constants. ${ }^{41}$

The Langmuir model assumes that adsorption forces are similar to chemical reactions, and there is no interaction between adsorbed species but only between these species and the adsorbent. Futhermore, adsorption on the adsorbent surface occurs up to the formation of a single, uniform layer (monolayer). The Freundlich model on the other hand, constituting one of the first proposed equations relating the amount of adsorbed ions to the concentration of a material in a solution, corresponds to the exponential distribution of adsorption values. ${ }^{33,42,43}$

The modified (two-site) Langmuir equation may overcome some of the constraints of the simple equation, such as the heterogeneity of solid phase sites involved in the adsorption. ${ }^{41}$ The Radke-Prausnitz isotherm has three adjustable parameters: $a_{R}, b_{R}$ and $\alpha_{R}$. At high concentrations, this model is transformed into the Freundlich isotherm, but at $\alpha_{R}=0$, yields the Langmuir isotherm. ${ }^{44}$

To choose the mathematical model that can be best adjusted to fit the experimental data and appropriately describe the adsorption system, the following conditions should be met: the highest (near-unity) $\mathrm{r}^{2}$ and lowest RMSE (root-mean-square error) values. According to Table 2, adsorption for BN can be described well by the Langmuir and Freundlich models, for - BS - by the two-site Langmuir model, for B-CA - by the Langmuir and Radke-Prausnitz models, and for B-CAS - by the Langmuir, Freundlich and Radke-Prausnitz models. Thus, the Langmuir model can characterize the chromium adsorption for all the samples, except BS.

Considering the results obtained from the non-linear Langmuir model, it is notable that the chemically modified materials adsorbed higher amounts of chromium ions, especially the sugarcane bagasse modified with $\mathrm{NaOH}$ and citric acid, B-CAS. The B-S and B-CA modifications were not viable given respective $q_{m}$ values were close to that for unmodified bagasse (BN). Comparing the $q_{m}$ value for 
Table 2. Isotherm parameters obtained using the non-linear method for chromium (III) adsorption on B-CA, B-CAS, B-S and B-N

\begin{tabular}{|c|c|c|c|c|c|}
\hline Isotherm & Adsorbent & B-N & B-S & $\mathrm{B}-\mathrm{CA}$ & B-CAS \\
\hline \multirow{5}{*}{ Langmuir } & $\mathrm{q}_{\mathrm{m}}\left(\mathrm{mg} \mathrm{g}^{-1}\right)$ & 20.34 & 21.40 & 26.20 & 58.00 \\
\hline & $\mathrm{b}\left(\mathrm{L} \mathrm{mg}^{-1}\right)$ & 0.004 & 0.070 & 0.004 & 0.021 \\
\hline & $\mathrm{r}^{2}$ & 0.736 & 0.531 & 0.912 & 0.945 \\
\hline & SSE & 36.10 & 118.30 & 17.20 & 32.90 \\
\hline & RMSE & 2.70 & 4.90 & 1.90 & 2.60 \\
\hline \multirow{5}{*}{ Freundlich } & $\begin{array}{l}\mathrm{K}_{\mathrm{f}}\left(\left(\mathrm{mg} \mathrm{g}^{-1}\right)\right. \\
\left.\left(\mathrm{L} \mathrm{mg}^{-1}\right)^{1 / \mathrm{n}}\right)\end{array}$ & 0.61 & 5.57 & 0.804 & 0.63 \\
\hline & $\mathrm{n}$ & 2.00 & 4.50 & 2.06 & 1.61 \\
\hline & $\mathrm{r}^{2}$ & 0.755 & 0.689 & 0.880 & 0.949 \\
\hline & SSE & 33.53 & 78.29 & 23.67 & 30.63 \\
\hline & RMSE & 2.60 & 3.90 & 2.20 & 2.50 \\
\hline \multirow{7}{*}{$\begin{array}{l}\text { Two-site } \\
\text { Langmuir }\end{array}$} & $\mathrm{K}_{\mathrm{A}}\left(\mathrm{L} \mathrm{mg}^{-1}\right)$ & $-1.10 \times 10^{-3}$ & $-1.20 \times 10^{-3}$ & 0.004 & 593.10 \\
\hline & $\mathrm{b}_{\mathrm{A}}\left(\mathrm{mg} \mathrm{g}^{-1}\right)$ & -1.40 & -3.40 & 26.22 & 7.73 \\
\hline & $\mathrm{K}_{\mathrm{B}}\left(\mathrm{L} \mathrm{mg}^{-1}\right)$ & $9.10 \times 10^{-3}$ & 0.22 & 271.9 & $7.70 \times 10^{-3}$ \\
\hline & $\mathrm{b}_{\mathrm{B}}\left(\mathrm{mg} \mathrm{g}^{-1}\right)$ & 12.70 & 15.70 & -0.29 & 78.20 \\
\hline & $\mathrm{r}^{2}$ & 0.788 & 0.830 & 0.913 & 0.910 \\
\hline & SSE & 29.10 & 42.97 & 17.22 & 54.37 \\
\hline & RMSE & 3.10 & 3.80 & 2.40 & 4.30 \\
\hline \multirow{6}{*}{$\begin{array}{l}\text { Radke- } \\
\text { Prausnitz }\end{array}$} & $\alpha_{\mathrm{R}}$ & 0.49 & 0.37 & 0.63 & 0.63 \\
\hline & $a_{R}\left(m g g^{-1}\right)$ & -111.60 & $1.60 \times 10^{4}$ & $6.60 \times 10^{-3}$ & $1.20 \times 10^{4}$ \\
\hline & $\mathrm{b}_{\mathrm{R}}\left(\mathrm{L} \mathrm{g}^{-1}\right)$ & 0.62 & 2.30 & 1883 & 0.59 \\
\hline & $r^{2}$ & 0.755 & 0.569 & 0.922 & 0.949 \\
\hline & SSE & 33.54 & 103.70 & 15.30 & 30.71 \\
\hline & RMSE & 2.90 & 5.21 & 1.96 & 2.70 \\
\hline
\end{tabular}

SSE is the sum-of-squared deviations of the points from the regression curve; RMSE is the residual root-mean-square error; $\mathrm{r}^{2}$ is the determination coefficient.

Table 3. Comparison of various biosorbents available for chromium (III) adsorption. Temperature: $25^{\circ} \mathrm{C}$

\begin{tabular}{lcccc}
\hline Adsorbents & $\mathrm{pH}$ & $\begin{array}{c}\text { Adsorbent } \\
\text { mass }(\mathrm{g})\end{array}$ & $\begin{array}{c}\mathrm{q}_{\mathrm{m}} \\
\left(\mathrm{mg} \cdot \mathrm{g}^{-1}\right)\end{array}$ & Ref. \\
\hline Sorghum straw & 4 & 0.05 & 9.35 & 17 \\
Oats straw & 4 & 0.05 & 12.10 & 17 \\
Agave bagasse & 4 & 0.05 & 28.72 & 17 \\
Raw rice bran & 5 & 0.02 & 0.13 & 18 \\
Vineyard pruning waste & 4.2 & 0.25 & 12.45 & 19 \\
Bacteria from tannery effluent & 4.5 & 0.5 & 28.80 & 20 \\
contaminated soil & & & & \\
Polymerized banana & 6.0 & 0.5 & 30.00 & 35 \\
Sugarcane bagasse (B-CAS) & 5.0 & 0.5 & 58.0 & $\begin{array}{c}\text { Present } \\
\text { study }\end{array}$ \\
\hline
\end{tabular}

B-CAS with other biosorbents (Table 3), a clear advantage in terms of maximum adsorption capacity is achieved with use of the chemically modified material.

\section{Thermodynamic parameters}

The adsorption thermodynamic parameters were calculated according to Equation $6(\Delta \mathrm{G}$, Gibbs energy) and Equation $7(\Delta \mathrm{H}$, enthalpy and $\Delta S$, entropy): ${ }^{22,43}$

$$
\begin{gathered}
\Delta G=-R T \ln K_{d} \\
\ln \mathrm{Kd}=(\Delta \mathrm{S} / \mathrm{R})-(\Delta \mathrm{H} / \mathrm{R}) 1 / \mathrm{T},
\end{gathered}
$$

where, $\mathrm{K}_{\mathrm{d}}$ corresponds to the ratio of $\mathrm{q}_{\mathrm{eq}}$ to $\mathrm{C}_{\mathrm{eq}}, \mathrm{R}=8.314 \mathrm{JK}^{-1} \mathrm{~mol}^{-1}$ is the gas constant, and $\mathrm{T}$ is the experimental temperature expressed in kelvin $(\mathrm{K})$. The enthalpy and entropy parameters and linear coefficients (Table 4 ) were obtained by plotting $\operatorname{lnKd}$ against $1 / \mathrm{T}$ (by calculating the slope of this line graph) and using Equation 7 (the van't Hoff Equation). The van't Hoff plot is not shown in this paper. The experiments were performed at the following temperatures: 10, 20, $30,40,50$ and $60^{\circ} \mathrm{C}$. The negative $\Delta \mathrm{G}$ (Gibbs energy) values, given in Table 4, indicate that chromium (III) adsorption on the biosorbents is energetically favorable, i.e., the adsorption process is spontaneous. ${ }^{43,45}$

Table 4. Thermodynamic parameters obtained from chromium (III) adsorption on sugarcane bagasse

\begin{tabular}{ccccc}
\hline Material & $\mathrm{K}_{\mathrm{d}}$ & $\Delta \mathrm{G}\left(\mathrm{kj} \mathrm{mol}^{-1}\right)$ & $\Delta \mathrm{H}\left(\mathrm{kJ} \mathrm{mol}^{-1}\right)$ & $\Delta \mathrm{S}\left(\mathrm{JK}^{-1} \mathrm{~mol}^{-1}\right)$ \\
\hline B-N & 17.20 & -7.00 & -42.15 & -117.95 \\
B-S & 36.20 & -8.83 & -38.00 & -97.93 \\
B-CA & 23.85 & -7.80 & -5.84 & 6.60 \\
B-CAS & 18.05 & -7.12 & -15.69 & -28.73 \\
\hline
\end{tabular}

After the bagasse modification, it was possible to verify a negative increase in the $\Delta \mathrm{G}$ values, demonstrating that the adsorption process in those modified adsorbents had led to a decrease in Gibbs free energy. The $\Delta \mathrm{H}$ adsorption values for the modified and unmodified bagasse were lower than $40 \mathrm{kJmol}^{-1}$, thus showing that the chromium (III) retention onto the adsorbent surface is defined by a physical adsorption process. ${ }^{46}$

The negative enthalpy values show the exothermic nature of the chromium adsorption, but also notable was the entropy values of less than zero (Table 4), demonstrating the occurrence of a certain order for the metal ions onto the adsorbent surface. This allowed the observation that the adsorption was governed by enthalpic factors as opposed to entropic factors. The only positive entropy value was obtained for B-CA, indicating greater disorder of the metal ions in the system, possibly due to the fact that the only reaction with citric acid produced more irregular surfaces.

\section{Chromium desorption}

As observed from Table 5, the highest desorption rate was obtained with B-CAS, in comparison with the other materials. The desorption rate can be considered satisfactory for possible reutilization of these materials as new adsorption phases. The high desorption value corroborates the low enthalpy value observed for B-CAS. The precision assessed in terms of repeatability based on the relative standard deviation (RSD) was evaluated for the bagasse modified with citric acid, whereas the RSD was found to be $2 \%$ for two cycles involving adsorption and desorption.

Table 5. Cr (III) adsorption-desorption values. Initial concentration: $890 \mathrm{mg} \mathrm{L}^{-1}$

\begin{tabular}{cccc}
\hline Material & $\begin{array}{c}\text { Adsorbed mass } \\
(\mathrm{mg})\end{array}$ & $\begin{array}{c}\text { Desorbed mass } \\
(\mathrm{mg})\end{array}$ & $\begin{array}{c}\text { Desorption rate } \\
(\%)\end{array}$ \\
\hline B-N & 6.3 & 4.1 & 65.1 \\
B-S & 11.4 & 10.2 & 89.5 \\
B-CA & 8.6 & 6.2 & 72.1 \\
B-CAS & 13.8 & 13.0 & 94.2 \\
\hline
\end{tabular}

\section{CONCLUSION}

The chemical modifications were confirmed with infrared data, and the band near $1730 \mathrm{~cm}^{-1}$ indicated the presence of the carboxylic group. A significant increase in chromium adsorption capacity was 
verified for all the modified materials, but was predominant for sugarcane bagasse modified with sodium hydroxide and citric acid. The adsorption process provided a good fit to Langmuir, Freundlich and Radke-Prausnitz non-linear models for B-CAS, and the chromium adsorption in the aqueous solutions followed pseudo-second-order kinetics. Additionally, the sugarcane bagasse chemical modifications rendered the system more energetically favorable, as demonstrated by the Gibbs free energy values. The process was considered exothermic, with a decrease in disorder. Finally, an improvement in chromium desorption after modifications was confirmed, indicating material reusability.

\section{ACKNOWLEDGEMENTS}

This study was supported by the UNIPAR (Universidade Paranaense). The authors would like to thank the CNPq (Conselho Nacional de Desenvolvimento Científico e Tecnológico), Fundação Araucária do Paraná, CAPES (Coordenação de Aperfeiçoamento de Pessoal de Nível Superior) and INCT for Bioanalytics (Instituto Nacional de Ciência e Tecnologia de Bioanalítica) for their financial support and fellowships.

\section{REFERENCES}

1. Özcan, A.; Özcan, A. S.; Tunali, S.; Akar, T.; Kiran, I.; J. Hazard. Mater. 2005, B124, 200.

2. Sari, A.; Tuzen, M.; Citak, D.; Soylak, M.; J. Hazard. Mater. 2007, 149, 283.

3. Karthikeyan, T.; Rajgopal, S.; Miranda, L. R.; J. Hazard. Mater. 2005, B124, 192 .

4. http://www.mma.gov.br/port/conama/legiano1.cfm?codlegitipo= 3\&ano=2005, acessada em Agosto 2011.

5. http://www.epa.gov/safewater/contaminants/basicinformation/chromium. html, acessada em Agosto 2011

6. Mahmoud, M. E.; Osman, M. M.; Hafez, O. F.; Elmelegy, E.; J. Hazard. Mater. 2010, 173, 349.

7. Sussulini, A.; Arruda, M. A. Z.; Eclec. Quim. 2006, 31, 73.

8. Castilho, D. D.; Vigor, C.; Tedesco, M. J.; R. Bras. Agroc. 1999, 5, 229.

9. Freitas, T. C. M.; Melnikov, P.; Eng. San. Amb. 2006, 11, 305.

10. Yun, Y. S.; Park, D.; Park, J. M.; Volesky B.; Environ. Sci. Technol. 2001, 35, 4353.

11. Sethunathan, N.; Megharaj, M.; Smith, L.; Kamaludeen, S. P. B.; Avudainayagam, S.; Naidu, R.; Agric. Ecosyst. Environ. 2005, 105, 657.

12. Ferreira, J. M.; Silva, F. L. H.; Alsina, O. L. S.; Oliveira, L. S. C.; Cavalcanti, E. B.; Gomes, W. C.; Quim. Nova 2007, 30, 1188.

13. Gundogdu, A.; Ozdes, D.; Duran, C.; Bulut, V. N.; Soylak, M.; Senturk, H. B.; Chem. Eng. J. 2009, 153, 62.

14. Veit, M. T.; Tavares, C. R. G.; Gomes-da-Costa, S. M.; Guedes, T. A.; Process Biochem. 2005, 40, 3303.

15. Vegliò, F.; Esposito, A.; Reverberi, A. P.; Process Biochem. 2003, 38, 953.

16. Nasernejad, B.; Esslam, Z. T.; Bonakdar, P. B.; Esmaail, B. M.; Zamani, A.; Process Biochem. 2005, 40, 1319.
17. Garcia-Reyes, R. B.; Rangel-Mendez J. R.; Bioresour. Technol. 2010, 101, 8099

18. Oliveira, E. A.; Montanher, S. F.; Andrade, A. D.; Nóbrega, J. A.; Rollemberg, M. C.; Process Biochem. 2005, 40, 3485.

19. Karaoğlu, M. H.; Zor, Ş; Uğurlu, M.; Chem. Eng. J. 2010, 159, 98.

20. Alam, M. Z.; Ahmad, S.; Clean: Soil, Air, Water 2011, 39, 226.

21. Sen, T. K.; Mohammod, M.; Maitra, S.; Dutta, B.K.; Clean: Soil, Air, Water 2010, 38, 850.

22. Jaman, H.; Chakraborty, D.; Saha, P.; Clean: Soil, Air, Water 2009, 37, 704.

23. Dos Santos, V. C. G.; Tarley, C. R. T.; Caetano, J.; Dragunski, D. C.; Water Sci. Technol. 2010, 62, 457.

24. Dos Santos, V. C. G.; De Souza, J. V. T. M.; Tarley, C. R. T.; Caetano, J.; Dragunski, D. C.; Water, Air, Soil Pollut. 2011, 216, 351.

25. Rodrigues, R. F.; Trevezoli, R. L.; Santos, L. R. G.; Leão, V. A.; Botaro, V. R.; Eng. San. Amb. 2006, 11, 21.

26. Júnior, O. K.; Gurgel, L. V. A.; Gil, L. F.; Carbohydr. Polym. 2010, 79, 184.

27. Martín-Lara, M. A.; Rico, I. L. R.; Vicente, I. C. A.; García, G. B.; Hoces, M. C.; Desalination 2010, 256, 58

28. Karnitz Jr. O.; Gurgel, L. V. A.; Melo, J. C. P.; Botaro, V. R.; Melo, T. M. S.; Gil, R. P. F.; Gil. L. F.; Bioresour. Technol. 2007, 98, 1291.

29. Pérez-Marín, A. B.; Zapata, V. M.; Ortuño, J. F.; Aguilar, M.; Sáez, J.; Lloréns, M.; J. Hazard. Mater. 2007, B139, 122.

30. Gurgel, L. V. A.; Júnior, O. K.; Gil, R. P. F.; Gil. L. F.; Bioresour. Technol. 2008, 99, 3077.

31. Ozsoy, H. D.; Kumbur, H.; J. Hazard. Mater. 2006, B136, 911.

32. Feng, N.; Guo, X.; Liang, S.; J. Hazard. Mater. 2009, 164, 1286.

33. Gurgel, L. V. A.; Melo, J. C. P.; Lena, J. C.; Gil, L. F.; Bioresour. Technol. 2009, 100, 3214.

34. Doğan, M.; Alkan, M.; Türkyılmaz, A.; Özdemir, Y.; J. Hazard. Mater. 2004, B109, 141.

35. Noeline, B. F.; Manohar, D. M.; Anirudhan, T. S.; Sep. Purif. Technol. $\mathbf{2 0 0 5}, 45,131$

36. Giles, C. H.; D`Silva, A. P. D.; Trivedi, A. S.; Surface Area Determination, London, Butterworth, 1970.

37. Dotto, G. L.; Vieira, M. L. G.; Gonçalves, J. O.; Pinto, L. A. A.; Quim. Nova 2011, 34, 1193.

38. Tarley, C.R.T.; Andrade, F. N.; Santana, H.; Zaia, D. A. M.; Beijo, L. A.; Segatelli, M. G.; React. Funct. Polym. 2012, 72, 83.

39. Ávila, R. C.; Segatelli, M. G.; Beijo, L. A.; Tarley, C. R. T.; Quim. Nova 2010, 33, 301

40. Galunin, E.; Alba, M. D.; Santos, M. J.; Abrão, T.; Vidal, M.; Geochim. Cosmochim. Acta 2010, 74, 862.

41. Liu, Y.; Liu, Y.; Sep. Purif. Technol. 2008, 61, 229.

42. Özacar, M.; Sengil, I. A.; J. Hazard. Mater. 2003, B98, 211.

43. Gonçalves, M.; Oliveira, L. C. A.; Guerreiro, M. C.; Quim. Nova 2008, 31,518 .

44. Schimmel, D.; Fagnani, K. C.; Dos Santos, J. B. O.; Barros, M. A. S. D.; Da Silva, E. A.; Braz. J. Chem. Eng. 2010, 27, 289.

45. Kurniawan, T. A.; Chan, G. Y. A.; Lo, W.; Babel, S.; Sci. Total Environ. 2006, 366, 409.

46. Kubilay, S.; Gürkan, R.; Savran A.; Sahan, T.; Adsorption 2007, 13, 41. 